\title{
腎結核に対する空洞切開術11例の検討
}

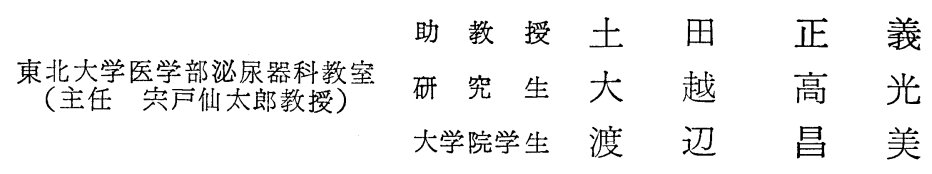

\section{ELEVEN CASES OF SPELEOTOMY}

\author{
Seigi Tsuchida, Takamitsu Ōgoe \\ Masami Watanabe
}

Form the Department of Urology, Tohoku University

School of Medicine

(Director: Prof. S. Shishito)

\section{I. 緒言}

空洞切開術は1953年 Staehler ${ }^{132) 3)}$ によつて発表され て従来, 腎結核に対する保存的手術療法として大きく評 価されるにようなつた. しかし, 本術式の適応, 手術手 技, 手術成績等に関して,な拉幾多検討の余地が残され ている. 私ごもは最近ての手術を11例経験したので, そ の成績を報告するとともに，以上の点について $2 ， 3$ の 検討を加えてみたい。

\section{II. 手術法}

私でもは本手術の適応と思われた腎結核11症例に対し て, Staehler の原法とこれに改良を加えた空洞緊縮法 を行なつた. そこで各症例の成績を述べる前に, まずそ れぞれの手術手技を述べる.

1. Staehler の原法

簡単に紹介すると，まず通常の腰部斜切開によつて腎 線維膜を露出する。つぎに空洞と思われる部分に穿刺針 を刺して内容を吸引し，空洞の存在を確認する。つぶい てその表面に切開を加え, 鋭匙を用いて空洞内容物を除 去する. 以上の操作が終つたならば, 空洞内に SM粉末 を撤布し，排液管を空洞内に留置して創を閉鎖する。

術後は毎日排液管を通じて空洞遺残部の貯留液を排除 すると〉もに，てれを通じて S M溶液を注入する，そし て排液量が少なくなつたならば, 術後 8〜14日頃に排液 管を拔去する。

\section{2. 空洞緊縮法}

術式の性質は $\mathrm{Rehn}^{4) 5)}$ が開放性病栄に行 なつている Kollapsbehandlung あるいは Couvelaire ${ }^{6 / 9)}$ が Spe- lēotomie己して発表している方法に近いものがあるが， 私ぎもは次のように行なつている.（第1図).すなわ ち, 腰部斜切開法で腎線維膜を露出してから空洞存在部 を確かめるまでの操作は, Staehler の原法と同様であ る.しかし空洞に切開を加えたならば，空洞円蓋部を腎 実質と〉もにできるだけ広範囲に切除する。すると切除 壁の腎実質から出血する場合があるから，との部分を細 いカットグートによる連続縫合で止血しておく,つがい て残存する空洞壁を健康な腎実質が露出するまで, 鋭匙 で丹念に描把する，この際腎実質からある程度出血する が, 後の縫合操作により完全に止血できる. 架洞は 1 個のみでなく, 同時に副空洞が数個発 見されることが 多いから，その場合には空洞相互間の隔壁も切除する。 また空洞はレ線上では閉鎖性と思われても, 実際には腎

第 1 図 私どもの行なつている空洞钘縮法

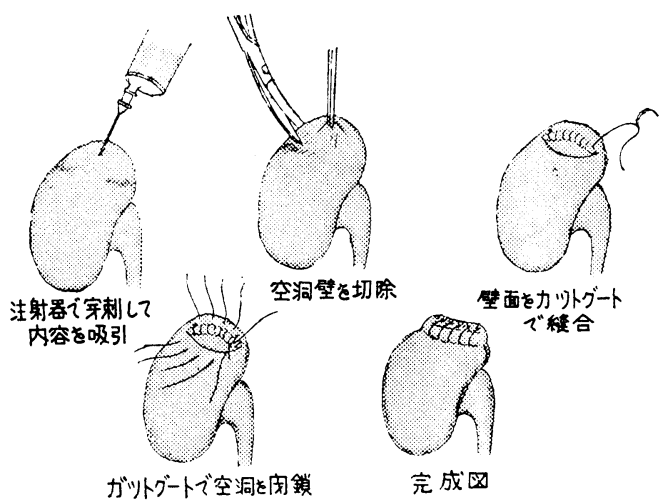


孟と交通している場合があるから、ソンテデ使用してて れを確かめる必要がある。もし認められたならば，ての 部分に細いカットグートをかけて閉鎖する。つぎにや> 大きい丸針を使用し， 4〜 5本のカツトグートを空洞壁 よりや>離れた腎被膜から空洞底部の腎実質を経由して 反対側の腎被膜に出るょうに通し，強めに結紮する. この操作の目的は, 掻把された空洞壁の出血を防止する そ〉もに，空洞の遗残腔を縫縮閉鎖するためである．し たがつて空洞の状態によつては，カツトグートのかけ方 を Mattress 縫合で行なつてもよい. 以上の操作が終つ たならば，出血がないととを確かめて創の閉鎖に移る が, この際, 排泄管を腎被膜外の後腹膜腔に 1 本だけ留 置しておく.

術後には, Staehler の方法と同様に，毎日貯留液を 排除してSM 溶液を注入する。けれぞも多くの場合，貯 留液は非常に少量であるから, 術後 $5 \sim 6$ 日に排液管を 拔去することができる。

\section{III. 症 例}

以下11症例の成績を述べる.

1. 年令, 性別, 病名, 患側㧍よび合併症

第 1 表に示す通りであるが, 症例 $3 \sim 6,11$ の 例注 すでに腎摘出術を受けて捛り, 症例 2 むずに他側に膿 腎を形成していたので, 空洞切開術に前後して腎摘出術 を受けた。 また症例 7 は左尿管狭窄を来していたので, 空洞切開術施行前に尿管膀胱吻合術を受けた. 合併症と しては, 症例 1,4 が右副幸丸結核を, 症例 8,10 は骨 関節結核を併発しいた。

2. 初発症状扮よび主訴

第 2 表に示すょうに, 初発症状について及ると, 頻 尿, 尿混濁等の尿路症状を訴えるものが多かつたが, 主

第 1 表 年令. 性別, 病名, 手術側, 合併症

\begin{tabular}{|c|c|c|c|c|c|}
\hline |症例 & 年令 & 性別 & 病 & 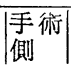 & 合 併 症 \\
\hline 1 & 31 & 男 & 左腎結核 & 左 & 右副睾丸結核 \\
\hline 2 & 24 & 男 & 両側腎結核 & 右 & なし \\
\hline 3 & 49 & 女 & 左残腎結核 & 左 & なし \\
\hline 4 & 39 & 男 & 左残腎結核 & 左 & 両側副鼻丸結核 \\
\hline 5 & 37 & 女 & 左残腎結核 & 左 & なし \\
\hline 6 & 38 & 女 & 左残腎結核 & 左 & なし \\
\hline 7 & 28 & 女 & $\begin{array}{c}\text { 両側㹂結核 } \\
\text { 結核性尿管狭窄 }\end{array}$ & 左 & なし \\
\hline 8 & 42 & 女 & 両側腎結核 & 左 & 骨関節結核 \\
\hline 9 & 24 & 女 & 左腎結核 & 左 & なと \\
\hline 10 & 29 & 女 & 左腎結核 & 左 & 骨関節結核 \\
\hline 11 & 35 & 女 & 右残腎結核 & 右 & なし \\
\hline
\end{tabular}

第 2 表 初発症状小よび主訴

\begin{tabular}{|c|c|c|c|c|c|c|}
\hline 症例 & \multicolumn{3}{|c|}{ 初 発 症 状 } & \multicolumn{2}{|c|}{ 主 } & 訴 \\
\hline 1 & \multicolumn{3}{|c|}{ 右鼻丸部腫脹 } & \multicolumn{3}{|c|}{ 右穓丸部鈍痛 } \\
\hline 2 & \multicolumn{2}{|l|}{ 発 } & 熱 & \multicolumn{2}{|c|}{ 血. } & 尿 \\
\hline 3 & \multicolumn{2}{|l|}{ 頻 } & 尿 & \multicolumn{3}{|c|}{ 左腰部不快感 } \\
\hline 4 & 尿 & 混 & 濁 & 左 & 腰 & 痛 \\
\hline 5 & 尿 & 混 & 濁 & 左 & 腰 & 痛 \\
\hline 6 & 頻 & & 尿 & 頻 & & 尿 \\
\hline 7 & 頻 & & 尿 & \multicolumn{3}{|c|}{ 左腰部不快感 } \\
\hline 8 & 関 & 節 & 痛 & \multicolumn{3}{|c|}{$?$} \\
\hline 9 & 頻 & & 尿 & 頻 & & 尿 \\
\hline 10 & 関 & 節 & 痛 & \multicolumn{3}{|c|}{$?$} \\
\hline 11 & 頻 & & 尿 & 尿 & 混 & 濁 \\
\hline
\end{tabular}

訴では，尿路以外に不定の愁訴导もつて訪れたもの，あ るい恮く愁訴を訴えぬものがあつた. すなわち症例 1 は右睪丸部疼痛があり, 右副蔂丸結核の診斷で入院中, 尿路レ線撮影により発見された。.症例 $3 \sim 5$ は腰部 不快感あるいは腰痛を訴えて来院したが，以前腎摘出 術を受けているので, 静脈性腎盂造影法が行なわれた結 果発見された. 一方定例 7 は, 左腰部不快感があり左尿 管狭窄と同時に発見された，さらに $8 ， 10$ はとくに尿路 症状を訴えたわけではなかつたが骨関節結核に合併した 腎結核を知るためのスクリーニングテストとして, 静脈 性腎孟造影法が行なわれた結果偶然発見された。

\section{3. 上線検查所見}

レ線㭘查は, 必要に応じて静脈性腎孟造影法, 逆行性 腎造影法こ後腹膜䏶送気法併用法掞よび大動脈撮影法を 実施した. 第 3 報には, レ線検查法の種類により, 後述

第 3 表 診断に役立つたレ線撮影法の種類 (○空洞の存在の推定できた場合) ○空洞の存在の確認できた場合)

\begin{tabular}{|c|c|c|c|c|}
\hline 症例 & $\begin{array}{l}\text { 静脈性腎 } \\
\text { 孟造影法 }\end{array}$ & $\begin{array}{l}\text { 逆行性腎要 } \\
\text { 造影法十後 } \\
\text { 腹膜送気法 }\end{array}$ & $\mid \begin{array}{c}\text { 大動脈 } \\
\text { 撮影法 }\end{array}$ & 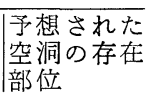 \\
\hline 1 & O & (2) & (2) & 左中極 \\
\hline 2 & 0 & () & O & 右下極 \\
\hline 3 & $\mathrm{O}$ & () & 施行せず & 左上, 下極 \\
\hline 4 & 0 & () & O & 左上，下極 \\
\hline 5 & 0 & (2) & 0 & 左下極 \\
\hline 6 & 0 & 0 & 0 & 左上極 \\
\hline 7 & 0 & 0 & 0 & 左上極 \\
\hline 8 & 0 & 0 & 施行せず & 左上極 \\
\hline 9 & $\dot{0}$ & (2) & 0 & 左上極 \\
\hline 10 & 0 & 0 & 0 & 左上極 \\
\hline 11 & 0 & 0 & (2) & 右下極 \\
\hline
\end{tabular}


の手術所見に対比して空洞の存在位置を決定するのに役 立つたと思われるものを示した。 との際, 私どもは一般 的䛦斷順序として，まず全例に静脈性腎孟造影法を行な つて，腎杯の一部または全部の欠除を発見し，空洞の存 在が推定されたならぼ, 逆行性腎孟造影法と後腹膜腔送 気法を併用した。 多くは，乙れにより，空洞と思われる 腎杯久損部とそれに対応した腎輪廓の膨隆を認め, 㳊ぶ 診斷を確定した。ささらに 9 例には大動脈撮影法を行なつ

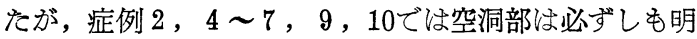
瞭に描出されなかつた。しふし症例 1,11 には, 明膫な 空洞部の陰影欲損を発見するととができた。（第 $2 ， 3$ 図).な扮, 症例 2 に対しては, 術前3年6力月にわたつて 定期的にレ線検查を行ない，経過学觀察するここができ たので，これについて記述する。すなわち第 4 図左は, 3 者併用療法開始時に押ける 静脈性腎盘造影像である が，右下腎杯頚部に狭窄がみられ，下腎杯は辺緑不整な 搪張像宗示していた。当時尿中結核菌は染色陽性であつ たが，化学療法開始 1 年後には染色培盖でこもに陰性と なり, 1 年 6 カ月後には静脈性および逆行性腎盂造影法 で下腎杯は全く造影されなくなつた。第 4 図右は手術前 つまり化学療法開始 3 年 6 カ月後の静脈性腎孟造影像で ある。

\section{4. 術前, 術後の尿検查成績}

手術直前拉よび術後 2 週〜 1 力月に打ける尿検查成績 を第 4 表に示した. 術前における尿の外觀は混濁 7 例, 清澄 4 例, 検鏡上膿球 1 視野 10 個以上 5 例, 赤血球 5 個 以上 5 例で, 結核菌は染色 おょび培養で症例 $11 の 1$ 例 のみに発見された。術後注術前と大差ない成績である

第 4 表 術前および術後の尿検査成績

\begin{tabular}{|c|c|c|c|c|c|c|c|c|}
\hline \multirow{2}{*}{ 症例 } & \multicolumn{3}{|c|}{ 術 } & 前 & \multicolumn{3}{|c|}{ 術 } & \multirow{2}{*}{$\frac{\text { 後 }}{\text { 結核菌 }}$} \\
\hline & 外観 & 膿球 & \begin{tabular}{|l} 
赤血 \\
球
\end{tabular} & 結核菌 & 外観 & 膿球 & \begin{tabular}{|l} 
赤血 \\
球
\end{tabular} & \\
\hline 1 & |混濁| & + & - & - & 清澄 & - & - & - \\
\hline 2 & 清澄 & - & - & - & 清澄 & - & - & - \\
\hline 3 & 混濁 & - & + & - & 混濁 & - & - & - \\
\hline 4 & 清澄 & - & - & - & 清澄 & - & - & - \\
\hline 5 & 混濁 & - & + & - & 混濁 & + & - & - \\
\hline 6 & 混濁 & + & + & - & 混濁 & + & - & - \\
\hline 7 & 混濁 & + & + & - & 混濁 & + & + & - \\
\hline 8 & 清澄 & - & - & - & 清澄 & - & - & - \\
\hline 9 & 混濁 & + & - & - & 混濁 & + & - & - \\
\hline 10 & 清澄 & - & - & - & 清澄 & - & - & - \\
\hline 11 & |混濁| & + & + & + & |混濁| & + & + & - \\
\hline
\end{tabular}

が, 症例 $1 ， 6$ において膿球または赤血球が消失し, 症 例11の尿中結核菌が消失した。 なおこの際，症例 2 ， $4,8,10 て ゙ は$ 術前, 術後を通じて, 尿所見は全く正常 であつた。

\section{5. 術前, 術後の腎機能}

術前と術後 1 力月または退院時におりる腎機能を，患 側青初発時間, PSP 30分值, Rest-N について測定し 第 5 表に示した。 まず青初発時間では，症例 6,7 が 5 分台から 4 分台へとわずかながら改善され，PSP 試験 では症例 6 が著明に改善された。 また Rest-Nの測定て は症例11が大巾に改善された。

第 5 表 術前, 術後の腎機能

\begin{tabular}{|c|c|c|c|c|c|c|}
\hline \multirow{2}{*}{ 症例 } & \multicolumn{2}{|c|}{$\begin{array}{l}\text { 患側の青初 } \\
\text { 発時間術 } \\
\end{array}$} & \multicolumn{2}{|c|}{$\begin{array}{c}\mathrm{PS} \mathrm{P30} \\
\text { 值 } \\
(\%)\end{array}$} & \multicolumn{2}{|c|}{$\begin{array}{l}\text { Rest-N } \\
\text { (mg/dl) }\end{array}$} \\
\hline & 術前 & 術後 & 術前 & 術後 & 術前 & 術後 \\
\hline 1 & $3^{\prime} 20^{\prime \prime}$ & $3^{\prime} 40^{\prime \prime}$ & 43 & 43.6 & 25.5 & 23.9 \\
\hline 2 & $4^{\prime} 12^{\prime \prime}$ & $4^{\prime} 10^{\prime}$ & 41 & 43.1 & 26.7 & 26.7 \\
\hline 3 & $\begin{array}{l}\text { 測定 } \\
\text { せず }\end{array}$ & $\begin{array}{l}\text { 測定 } \\
\text { せず }\end{array}$ & $\begin{array}{l}\text { 測定 } \\
\text { せず }\end{array}$ & $\begin{array}{l}\text { 測定 } \\
\text { せず }\end{array}$ & $\begin{array}{l}\text { 測定 } \\
\text { せず }\end{array}$ & $\begin{array}{l}\text { 測定 } \\
\text { せず }\end{array}$ \\
\hline 4 & $3^{\prime} 45^{\prime \prime}$ & $3^{\prime} 50^{\prime \prime}$ & 25 & 25 & 24.3 & 35.7 \\
\hline 5 & $3^{\prime} 10^{\prime \prime}$ & $3^{\prime} 20^{\prime \prime}$ & 40 & 41 & 24.3 & 22.2 \\
\hline 6 & $5^{\prime} 30^{\prime \prime}$ & $4^{\prime} 50^{\prime \prime}$ & 30 & 42 & 25.6 & 28.2 \\
\hline 7 & $5^{\prime} 15^{\prime \prime}$ & $4^{\prime} 50^{\prime \prime}$ & 29 & 28 & 28.8 & 20.2 \\
\hline 8 & $3^{\prime} 50^{\prime \prime}$ & $3^{\prime} 45^{\prime \prime}$ & 42 & 43 & $\begin{array}{l}\text { 測定 } \\
\text { せず }\end{array}$ & $\begin{array}{l}\text { 測定 } \\
\text { せず }\end{array}$ \\
\hline 9 & $5^{\prime} 10^{\prime \prime}$ & $5^{\prime} 10^{\prime \prime}$ & 36 & 33 & 26.2 & 33.0 \\
\hline 10 & $4^{\prime} 50^{\prime \prime}$ & $4^{\prime} 30^{\prime \prime}$ & 45 & 42 & $\begin{array}{l}\text { 測定 } \\
\text { せず }\end{array}$ & $\begin{array}{l}\text { 測定 } \\
\text { せず }\end{array}$ \\
\hline 11 & $5^{\prime} 40^{\prime \prime}$ & $\begin{array}{l}\text { 測定 } \\
\text { せず }\end{array}$ & 12 & 15 & 62.7 & 47.0 \\
\hline
\end{tabular}

6. 手術所見

手術所見安第 6 表に示した。手術法は症例 1 から 5 \% での5例には Staehler の原法を, 症例 6 から 11 ま゙の 6 例には空洞緊縮法を行なつた. この際，手術時に実際 に確認された空洞の存在部位と数を, 前述のレ線像から 予想したもの（第 3 表）と比較すると，空洞の存在部位 は症例 5 を除いてほ心゙適中した。しかし空洞数について みると，レ線上では 1 個と思われても, 多くの場合 2 数個の副空洞が発見された。

7. 術前化学療法期間, 空洞内結核菌検出成績, 空洞 内 ${ }^{131}$ I-Hippuran 排泄量, 術後瘦孔閉鎖までの期間およ びこれらの相互関係

以上の項目については，その相互関係を検討する必要 上から，一括して第7表に示した。

まず術前に行なわれた化学療法の性質は，3 者併用療 法を主体としているが，その期間についてみると，1カ 
第 2 図

症例 1 の逆行性肯盂造影法, 後腹膜症例 1 の大動脈造影法. 中極に円形 送気法の併用像. 中腎杯が造影さ の軨廓をもつた映像の淡明部分が れない. 六られる。

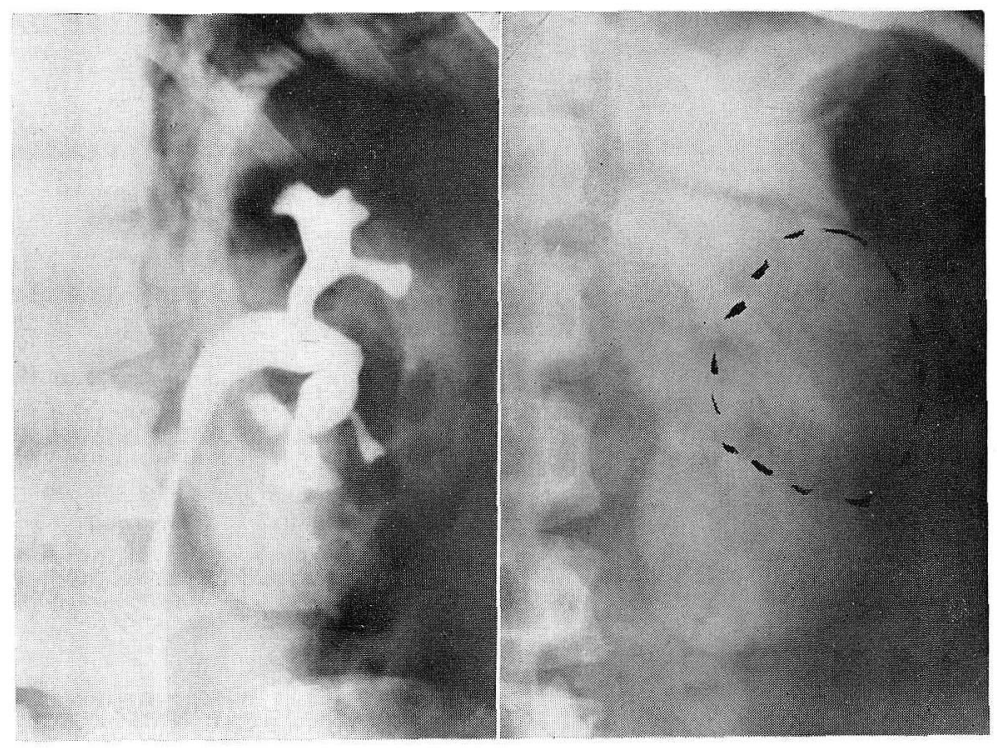

第 3 図

症例11の大動脈造影像腎下極に向 5 動脈技が些少になり枯木像を示し

症例11の静脈性腎杰造影像. 右下腎 ている。該部の㛑寒質も全く造影

杯が圧迫され歪曲している。 されない。
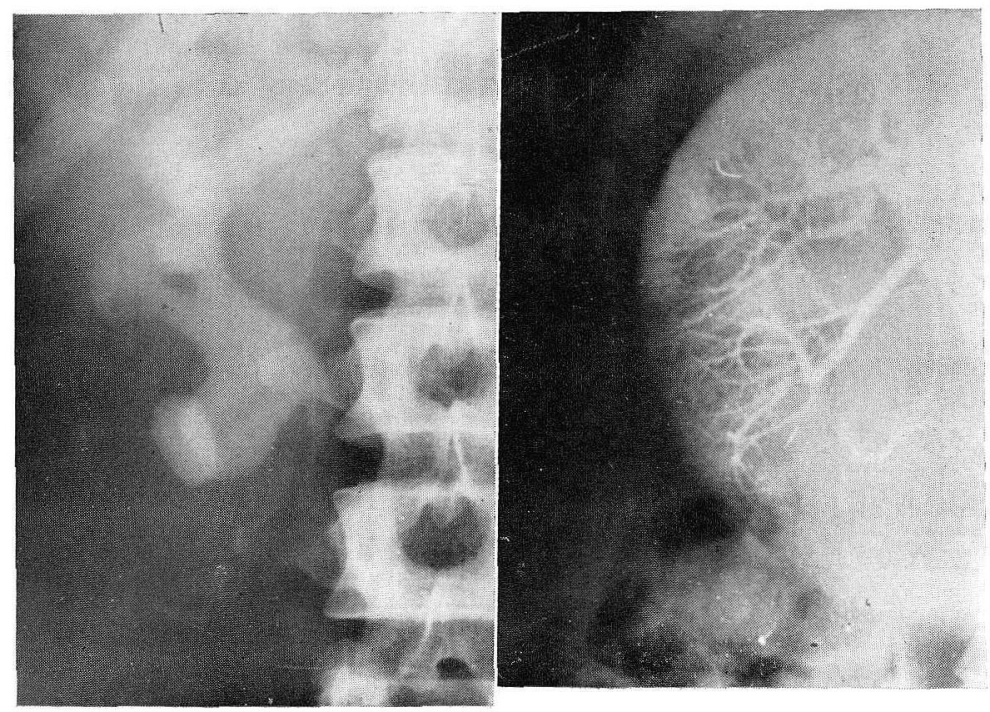
第 4 成

症例 2 の化学療法開始特にお汀る静 脈性腎責造影像. 右下珡杯灶辺縁 不整な搪張像劣している。
症例 2 の 3 年 6 力月後に括的る静脈 性腎盎造影像。下腎杯は全く造影 されなくなつた。

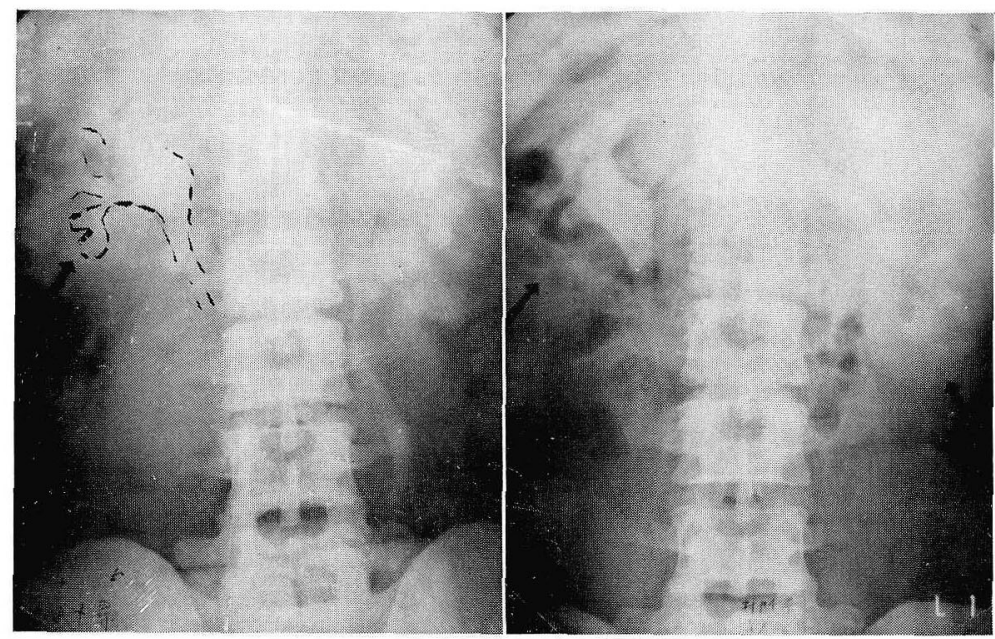

第 6 表 手術所見

\begin{tabular}{|c|c|c|c|}
\hline 症例 & 手 術 法 & $\begin{array}{l}\text { 空洞の存在 } \\
\text { 空洞数 }\end{array}$ & 乌位と \\
\hline 1 & \multirow{7}{*}{$\begin{array}{c}\text { Staehler } \\
\text { 原 法 }\end{array}$} & 左中榿 & 1 個 \\
\hline 2 & & 右下權 & 3 個 \\
\hline 3 & & 左上, 下極 & 数個 \\
\hline 4 & & 左上, 下極 & 数個 \\
\hline 5 & & 左:上, 下極 & 数個 \\
\hline 6 & & 左上極 & 数個 \\
\hline 7 & & 左上極 & 数個 \\
\hline 8 & \multirow[t]{4}{*}{ 架洞緊縮法 } & 左上極 & 3 個 \\
\hline 9 & & 左上極 & 数個 \\
\hline 10 & & 左上極 & 2 個 \\
\hline 11 & & 右下極 & 数個 \\
\hline
\end{tabular}

月から約 5 年の長さに扮よんでいる。

つぎに手術時に架洞内容物から染色执小び培養法で結 核菌が検出されたの怯, 症例 $1,3,6 \sim 7,1196$ 例 である。一方，私ざもは空洞自体に残存している腎機能 を推定するために、つぎの小うな試及岩行なつた。すな わち第 5 図のように, 症例 1,7 定除々 9 例飞手術開始 3 時間前已, 手術開始時飞 ${ }^{13}$ I-Hippuran $100 \mu \mathrm{c}$ 学静 脈内に注射し，との間に排泄され\%膀胱尿招よび手術時 に採取され空洞内容物の Count 数省 GM管によつて 計数した. こして前者に対严る後者の比率学計算して表 示した.
第 5 図 ${ }^{131}$ I-Hippuron 静注:

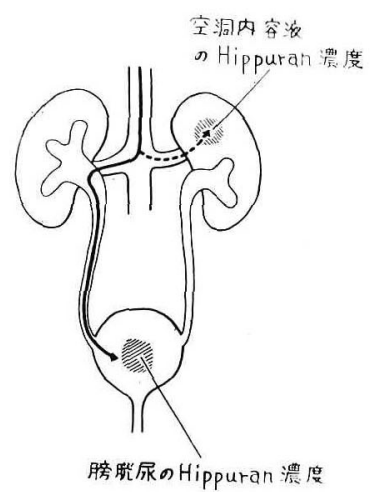

つぎに術後瘦孔が鐄鎖するるでの期閒定みると，原法 の行なわれた 5 例のうち症例 $1 \sim 3$ の術後経過 は順調

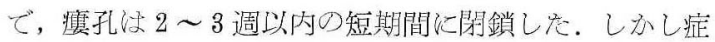
例 4 は術後 3 日より排泄量が次第に増加して 1 日60 cc 位 となつて 2 週間以上持続した。 そして 3 週後排液管を拢 去してからも，瘦孔悩容易に閉鎖せず，しばしば $38^{\circ} \mathrm{C} 〜$ $39^{\circ} \mathrm{C}$ の発熱を繰返してい炎が, 術後75日にようやく閉鎖 し\%。症症例 5 々, 術後 1 週頃から排液量が急速に増 加し, その成分も透明な尿となり, 量も 1 日 $200 \mathrm{cc}$ 程度 に達した。そして術後 2 力月学経過しても全く減少せ ず，完全な尿瘦昰形成するょうになつ火。 その後約 8 力 月湶ぞ同じ状態が継続したが，術後10力月頃より尿量が 
第 7 表 術前化学療法期間，空洞内結核菌檢出成績,驾洞内 ${ }^{131}$ I-Hippuran 排泄量, 瘦孔閉鎖期間

\begin{tabular}{|c|c|c|c|c|c|c|c|c|}
\hline 症 & 手 & 法 & 術前化学 & 療法期間 & 空洞内 & 桔菌 & $\mid \begin{array}{l}{ }^{131} \text { I-Hippruan 空洞内排泄 } \\
\text { 量 (倿胱尿に対する比率) }\end{array}$ & 瘻孔閉鎖期間 \\
\hline 1 & \multirow{8}{*}{\multicolumn{2}{|c|}{$\begin{array}{l}\text { Staehler の } \\
\text { 原 法 }\end{array}$}} & & 1 力月 & 陽 & 性 & 测定せず & 2 週間以内 \\
\hline 2 & & & 3 年 & 6 力月 & 陰 & 性 & $1.2 \%$ & 2 週問以内 \\
\hline 3 & & & 2 年 & & 陽 & 性 & 1.5 & 3 週間以内 \\
\hline 4 & & & 1 年 & & 㓌 & 性 & 3.3 & $75 日$ \\
\hline 5 & & & 2 年 & & 陰 & 性 & 5.2 & 1 年 6 力月 \\
\hline 6 & & & 3 年 & & 陽 & 性 & 0.5 & \multirow{6}{*}{2 週間以内 } \\
\hline 7 & & & 3 年 & & 陽 & 性 & 測定也ず & \\
\hline 8 & & & \multirow{4}{*}{\multicolumn{2}{|c|}{$\begin{array}{l}2 \text { 年 } \\
1 \text { 年 } \\
\text { 約 } 5 \text { 年 }\end{array}$}} & 陽 & 性 & 1.4 & \\
\hline 9 & \multirow{3}{*}{\multicolumn{2}{|c|}{ 空洞緊繀法 }} & & & 陰 & 性 & 6.1 & \\
\hline 10 & & & & & 㓌 & 性 & 1.4 & \\
\hline 11 & & & & & 陽 & 性 & 0 & \\
\hline
\end{tabular}

第 6 図

症例 5 の術前に和ける静脈性暨盂造 影像，左下筒杯は全く造影されな ᄂ.

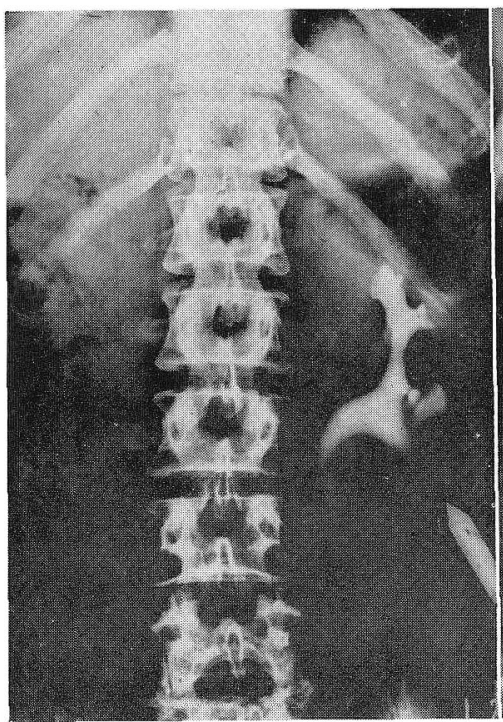

や\減少し始めだで排液管在拔去した，第 6 図ほ術前 扮よび排液管拔去直後すなすち術後䄪11力月に持ける静 脈性腎需造影像じあるが，空洞伦置に相当する腎下極部

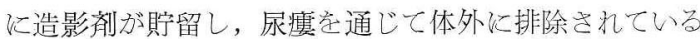
ととがわかる。との患者はその後もしばしば発熱し，㾇 孔よりかなりの量の尿学排出していたが，術後 1 年 6 力 月にようやく瘦孔が閉鎖した。

空洞緊縮法の行なわれた 6 例では, 排液管からの排出
症例 5 の術後約 11 力月に打忊る静脈

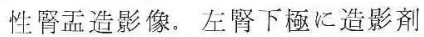
が貯細しているのがわかる。

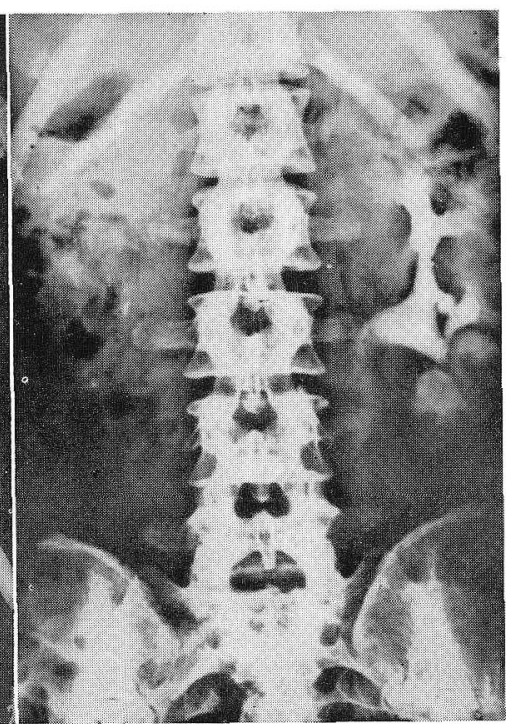

液は 5〜10 c と非常に少なく, 術後10日頃に排液管李拢 去したが，全例に扎いて瘦孔は術後 2 週間以内に閉鎖し te.

さて以上の㛟查項目について，きず空洞内結核菌検出 成績乞術前化学療法乞の関係宏みると, 化学療法期間の 短い症例 1，8では陽性さなつているが, 症例11のよう に期間の長い例飞怙いても陽性であり，両者の間に必ず しも正しい相互関係怡られなからた。つぎ空洞内 
${ }^{131}$ I-Hippuran濃度と結核菌検出成績乞の関係をみると, 空洞内濃度が高い症例 $4,5,9$ で陰性であり, 比較的 低い症例 $3 ， 6,8,11$ に扮いて陽性こいう関係が得ら れた. 最後に空洞内の ${ }^{131} \mathrm{I}$-Hippuran 濃度と瘦孔閉鎖期 間を, 原法が実施された症例だけについてみるこ, 空洞 内 ${ }^{{ }^{31} \mathrm{I}-H r p p u r a n}$ 濃度の高い症例 $4 ， 5$ の瘦孔閉鎖期間 が長びいたととが判明し尽。

\section{IV。考按}

空洞切開術は1935年 Heitz-Boyer ${ }^{7)}$ が靔ひ閉鎖性空洞 に対し，その円蓋部学電気スで切除，内容物学排除して 治瘾させたのが最初である。しかし当時はただ化学療法 以前の時代であり, 結核性感染の危険性から, 一般に行 なわれるには至らなかつた。ところが1953年になつて Staehler' ${ }^{1}$ がこれ再び取上げ，その術式孛 Kavernotomie こしてドイツ外科学会に発表して以来，腎結核に対 する保存的手術療法こして再認識されるようになつた. その後 Aboulker \& Wetterwald ${ }^{8)} 7$ 例の成績を報告 すると〉もに，本手術は腎部分切除術を行なえないよう な重症例にも実施するととができると述べ, Couvelaire ${ }^{6) 9)}$ も類似の方法を Spēlēotomie として 発表してい る.その添か Staehler 門下の Gunst ${ }^{10)}$ は14例を, Frumkin \& Buckmann ${ }^{11)}$ は 4 例安経験報告している. まLjunggren ${ }^{1213)}$ も空洞切開術は腎の閉鎖性病変に対 して腎部分切除術に匹敵する効果をあげるここができる と述べている。わが国でも, 大越ら ${ }^{14)}$, 南 ${ }^{15) 16}{ }^{13}$ 行なつて いずれもよい結果を得たこ報告しているが，乙の際大越 19)は腎結核に対する保存的療法こして，1956年学境に， それ以前は腎部分切除術を, それ以後は主として空洞切 開術を行なうようになつ\%と述べて本法の有用性を評価 している.

空洞切開術の適応さなるのは，Staehler ${ }^{2) 3}$ によれば 腎跙と交通のない閉鎖性空洞である。しかし私ごもの症 例にみるように, 本手術対象例の主訴は, 腰部不快感, 腰 痛等非定型なものが多く，場合によつては全く愁訴がな い場合もある.さらに尿所見が完全に正常な場合もあ る、したがつてその診斷は必ずレ線検查によなければな らない.こころが閉鎖性空洞は静脈性腎孟造影法または 逆行性腎孟造影法によつて描出されないので, 病巣部の 決定はや〉容易でない。しかし Staehler ${ }^{2) 3}$, Gunst $^{10)}$ は，つぎのようにしててれを発見できると述べている。 すなわち腎結核に招ける閉鎖性空洞の大部分は，腎杯 頚部の狭窄によつてまず水，膿腎杯を形成し，とれを母 体として発生するのが大部分である。したがつてそのよ
ろな場合には, 静脈性腎孟造影像字よく調べてみると, 正 常な場合にはみられるはずの腎杯系が一部欠如している ととによつて，添㜔当がつく、たざある種の空洞は腎 杯系と関係なく皮質に発生するとともある，彼らはこの よろな場合でも，あたかも腎腫瘍や腎囊腫に扣けるよろ に，腎杯が空洞によつて圧迫された所見を示しているこ こから判定がつくこ述べている。浪た逆行性腎㙉造影法 己後腹膜送気法を併用して実施するのも有胶な方法であ

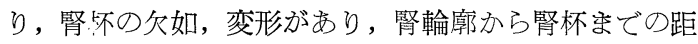
離が延長するとつもに，乙れに相当して腎輪廓の膨隆が 発見され〉ば, 空洞の存在は汪ざ確実である。一方, Gilvernet ${ }^{20)}$ は腎血管造影法を経時的に行なえば空洞部 孛明膫に描出できると述べて㧍り，Ljunggren ${ }^{13)}$ も空洞 の診㫁に腎血管造影法が非常に有效なととを述べてい る.

私ごもはすず，静脈性餐孟造影法，逆行性腎孟造影法 こ後腹膜送気法併用法を全例に施行した。 その結果静脈 性腎瑥造影法は空洞の存在を推定するのに有効であり， 逆行性腎孟造影法と後腹膜送気法併用法では, 空洞の存 在を推定するのに役立つばかりでなく，6 例にこれを確 認するここができた。を大動脈撮影法も 9 例に行ない。 2 例に扣いて空洞存在の確認に役立つている.しかし以 上のレ線診斷所見こ手術所見を比較するこ，空洞すべて の症例に発見されたが, 症例 5 に捛いては, レ線上みら れなかつた左上極部にも発見されている。したがつて手 術時には, 憼全体の被膜索露出して病変部を丹念に検索 する必要が感じられる。

つぎに手術時の空洞内容物からの結核菌検出成績であ るが, 岡元・阿世知 ${ }^{18)}$ は 7 例中 2 例に結核菌を証明した こ報告して扮り。私ごもは11例中 6 例に証明した。 この 際問題こなるのは, 結核菌が陰性であつた空洞である. 一般に空洞内結核菌検出成績は化学療法期間に逆比例す るといわれているが，乙れに対して Kairis ${ }^{21)}$ は化学療 法を10年以上継続した場合にも閉鎖性病巣中に結核菌を 発見したと述べている。 尔た Ljunggren ${ }^{13)}$, Kanzler ${ }^{22)}$ はじめ多くの学者は, 化学療法の効果には, 化学療法の 持続期間よりも病巣局所の腎機能が非常に関係するこ述 べている。すなわち薬刜は腎血流によつて病巣に到着す ると〉もに，尿中に排泄されて尿に溶解した状態でも病 巣に作用するといわれている。私ざもの症例における空 洞内結核菌検出成績己化学療法期間の相互関係を調べる 己, 化学療法期間が 3 力月以下々比較的短かつた 2 例で は陽性であつた。しかし化学療法が約 5 年こ長期行なわ れた症例にも結核菌が証明されて扮り, それが化学療法 
の期間に必ずしも関係しないことを知つた。 そこで私ど むは，この関係を空洞局所の腎機能に結びつけて考える ために, 空洞内 ${ }^{131}$ I-Hippuran 排泄濃度から检討してみ た. すなわち GM 管により空洞内容物 および膀胱尿 Co.unt数を測定した結果, Hippuran空洞内排泄濃度が膀 胱尿の $3.3 ， 5.2 ， 6.1 \%$ と比較的高い 3 例では空洞内 結核菌は陰性であり，反面症例 $3 ， 6 ， 8 ， 11$ 等のよう に低い場合には陽性となつた。 Hippuran は腎機能すな わち組織の血流量を現わすものである. 一方 Dick \& Stevenson ${ }^{23)}$, Hoess ら ${ }^{24)}$ とより腎機能に比例して抗結 核郕が排泄されるというととが証明されているから，空 洞内にHippuranが多量に排泄され〉ば，抗結核凨もよく 到達すると考えてょかろろ。したがつて早期に完成され た閉鎖性空洞では, 周辺の血流が悪く, 抗結核郕の到達 あ不良である。沉えにいかに長期間化学療法を行なつて も結核菌の絶隇はなかなか困難であり，こういう点から も閉鎖性空洞に対しては空洞切開術が必要ないことを示 していると思われる。

もつとも空洞内 Hippuran濃度がすべての場合空洞内 結核菌検出成樍に関係するわけではなく，空洞が完成さ れた時期的関係も考慮しなりればならない.すなわち， 症例 2 は右腎下極部に空洞が発見された例であるが，こ の際空洞内 Hippuran 濃度は $1.2 \%$ とかなり低かつた。 ところがレ線像の経時的変化を追つてみると, まず化学 療法開始時には, 右下極の病巣は不鮮明ながらながら描 出され，との部分に腎機能が保持されていたととを示し ている. しかし 1 年 6 カ月後には尿中結核菌が㓌性化す ると〉もに下腎杯は完全に描出されなくなり, 空洞を形 成するに至つた。つまりこの症例では化学療法中に病巣 の清静化が進及結核菌が消失してから， Gloor ${ }^{25)}$ のいう 腎杯頚部の切斷 (Kelchamptation) が起つて空洞を形 成したものと考えられる，ところでとのように空洞内の 結核菌が消失した症例には, 空洞切開術は不要であろう という考えも起つてくる. しかし Staehler ${ }^{2 / 3)}$ は.その場 合にも, 乾酪性物質を充満した緊張性空洞は周囲の健康 な腎組織を圧迫して血流供給を妨げ，腎機能を悪化させ るから, 本手術が必要であると述べている.私どもの症例 では術後 2 例における青初発時間がわずかに改善され， 他の 2 例では PSP 30 分值, Rest-N が大巾に改善され ており, Staehler の考えをほぶ支持するととができる.

以上のように, 空洞切開術は多くの点で秀れた手術法 である．しかしその術式を Staehler の原法に従つて行 なろと，術後排液管扦入部にしばしば庭孔ないし尿庭を

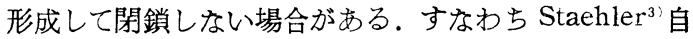
身, 術後 2 週間に尿㾯学形成した症例を経験している.

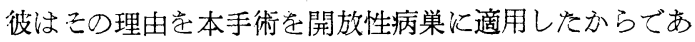
つて, 閉鎖性病巣に行なえばこういうことはない筈だと 述へている．しかしての釈明はや〉当を得ないように考 えられる。 と>で, Staehler のいう, 空洞の開放 性, 閉鎖性という分け方であるが，彼や Gunst' ${ }^{10)}$ はじ め多くの学者の考えはもつぱらレ線像の所見からだけい つているょうである. 彼らの手術例には術前に尿中結核 菌が踼性であつたものが，術後陰性化している例がある が, こういう症例では, レ線像からは認められなくて も, 空洞と腎孟間に微細な交通路が存在し，こ>から結 核菌が排泄されていたに違いない. この点私どもはStaehler ${ }^{2) 31}$ とは見解を異にしており，Staehler の原法を行 なつた場合に，尿瘦形成に関係する空洞の性質は，上線 像からいう閉鎖性, 開放性という区別ではなく, 前述し た空洞自体に残存する腎機能如何に関係するのであろう と考えている。こういう觀点からもう 1 度原法実施症例 を検討してみると, 空洞内 Hippuran濃度の低かつた症 例 2,3 の瘦孔は術後 $2 \sim 3$ 週以内に閉鎖している. れに反して, 排泄量の多かつた症例 $4 ， 5$ に执いて度孔 閉鎖期間が非常に遅れている.すなわち, 未だ腎機能が 残つている空洞に単なる切開を行なつて排液管を設置す るととは,丁度腎㾇術を行なつたのと同じ結果になる.空 洞自体の腎機能が働いて尿の排泄が続いている限り, 容 易に㾯孔ないし尿漊が閉鎖しないのは理の当然てあ 5. この点ではStaehlerの原法は手術手技の上に再考の 余地があり, 術後尿庵学形成する恐れの少ない空洞緊縮 法を行なう方が望ましい。

\section{V. 結 語}

腎結核に対する保存的手術療法である空洞切開術の術 式について，Staehlerの原法ととれに改良を加えた空洞 緊縮法の術式を紹介し, 前者 5 例, 後者 6 例計 11 例の経 験を述べた。

1. 初発症状としては，尿路症状交訴えるものが多か つたが, 主訴では腰痛等, 尿路以外の不定の症状を訴え るものが大部分であつた。

2. 術前の検尿所見についてみると, 結核菌湯性は 1 例であつたが, 術後に全例が陰性化した. しかし術前, 術後を通じて尿所見が全く正常な症例もみられた。

3. 術前, 術後の腎機能についてみると, 数例におい て腎機能が改善された。

4. 訩斷に役立つたレ線検査法では, 逆行性腎孟造影 
法と後腹膜送気法併用法おつよび大動脈撮影法が病巣の存 在を確認するのに役立ち, 静脈性腎孟造影法はこれを推 定するのに役立つた。

5. 手術時に空洞内容物から結核菌が証明されたのは 11 例中 6 例であつた.

6. 空洞緊縮法を施行した 6 例では, 術後 2 週以内に 全例の庵孔が閉鎖した.しかし Staehler の原法を施行 した 2 例には術後尿瘦を形成した。

（御指導，御校閲下さつた恩師宾戸教授汇深く感謝し ます)

\section{交献}

1) Staehler, W.: Arch. klin. Chir., 276, 319, 1953.

2) Staehler, W.: Medizinische, 1954, 943.

3) Staehler, W.: Klinik und Praxis der Urologie. s. 217, Georg Thieme Verlag, Stuttgart, 1959.

4) Rehh, E.: Arch. klin. Chir., 276, 321, 1953.

5) Rehn, E.: Medizinische, 1953, 337.

6) Couvelairé, R. \& Auvert, J.: Urol. internat., 6, 91, 1958.

7) Heitz-Boyer, M.: J. Urol. Med. chir., 39, 484, 1935.
8) Aboulker, P. \& F. Wetterwald: Acta Urol. Belg., 24, 240, 1956.

9) Couvelairé, R.: J. d' Urol., 65, 1959.

10) Gunst, W.: Zschr. Urol., 50, 177, 1957.

11) Frumkin, A.P. \& A.A. Buchmann: Zschr. Urol., 53, 479, 1960.

12) Ljunggren, E.: Handbuch der Urologie, s. 1, Springer Verlag, Berlin, 1959.

13) Ljunggren, E.: Med. J. Aust., 47-I, 322, 1960.

14）大越ら：日泌尿会誌. 51,109 , 昭 35 .

15）南：外科治療, 2, 161, 昭35.

16) 南: 手術, 14,387 , 晤 35 .

17) 岡元, 阿世知: 皮と泌. 22,405 , 昭 35.

18）岡元, 阿世知：日泌尿会誌. 52,752 , 昭 36.

19）大越：日泌尿会誌. 54,508 , 昭 38 .

20) Gil-vernet, J.M. et al.: Urol. Belg., 28, 5, 1960.

21) Kairis, Z.: Urologia, 27, 130, 1960.

22) Kanzler, W.: Med. Mschr., 13, 589, 1959.

23) Dick, J.C\& J.S. Stevenson: Brit. J. Urol., 24, 179, 1952.

24) Hoess, H. et al.: Urol. int., 3, 114, 1956.

25) Gloor, U.: Schw. Med. Wschr.: 90, 513, 1960.

（昭和 39 年 1 月 13 日受付） 